\title{
MENGURANGI KECEMASAN SISWA DALAM MENGHADAPI UJIAN SEMESTER MELALUI KONSELING KELOMPOK GESTALT
}

\author{
Wa Ode Husniah ${ }^{1}$, Maria Ulfa, S.Pd., M.Si ${ }^{2}$ \\ Email: odehusniah@gmail.com ${ }^{1}$; ulfa.razak88@gmail.com ${ }^{2}$ \\ Program Studi Bimbingan dan Konseling, Fakultas Keguruan dan Ilmu Pendidikan, \\ Universitas Muhammadiyah Buton
}

\begin{abstract}
Abstrak
Tujuan penelitian ini untuk mengetahui pelaksanaan konseling kelompok Gestalt dan untuk mengetahui tingkat kecemasan siswa kelas VIII SMP Negeri 5 Wangi-wangi. Jenis penelitian ini menggunakan metode Pre Eksperimen dengan desainOne Group Pre-test and Post-test Design. Populasi penelitian ini adalah siswa SMP Negeri 5 Wangi-wangi yang jumlah 123 siswa. Teknik pengambilan sampel yaitu menggunakan purposive sampling di mana sampel berjumlah 12 siswa dari siswa kelas VIII SMP Negeri 5 Wangi-wangi. Teknik analisis data di lakukan dengan menggunakan analisis uji wilcoxon dari data gain menggunakan SPSS versi 16.0 for windows dengan melihat perbandingan nilai signifikansi atau Asymp. Sig (2-tailed)< 0.05, maka hipotesis di terima, namun jika nilai signifikansi atau Asymp. Sig (2-tailed)> 0.05 maka hipotesis ditolak. Hasil penelitian menunjukkan gambaran siswa sebelum diberikan Konseling Kelompok Gestalt pada hasil pre-test kategori tinggi 8 siswa dengan presentase $(100 \%)$ kategoti sedang $(0 \%)$ dan kategori rendah $(0 \%)$. Dan pada hasil post-test kategori tinggi (0\%), kategori sedang 3 siswa dengan presentase $37 \%$ dan kategori rendah 5 siswa dengan presentase 63\%. Pada uji wilcoxon di gunakan untuk membandingkan perbedaan nilai pre-test dan post-test pada kelompok eksperimen, sehingga memperoleh nilai signifikansi atau Asymp. Sig (2-tailed) $0.001<0.05$, maka hipotesis di terima.yang berarti dapat Disimpulkan bahwa Konseling Kelompok Gestalt efektif mengurangi kecemasan siswa menghadapi Ujian Semester siswa kelas VIII SMP Negeri 5 Wangi-wangi. Berdasarkan hasil penelitian tersebut maka saran yang dapat disampaikan yaitu hendaknya konselor lebih bervariatif dan meningkatkan frekuensi pemberian layanan informasi untuk membantu siswa dalam mengurangi Kecemasan siswa menghadapi Ujian Semester secara tepat.
\end{abstract}

Kata kunci: Konseling Kelompok Gestalt; Kecemasan Siswa

\begin{abstract}
The purpose of this study was to study the implementation of Gestalt group counseling and to determine the level of students of class VIII of SMP Negeri 5 Wangi-Wangi. This type of research uses the Pre Experiment method with One Group Pre-test and Post-test Design. The population of this study were 123 students of SMP Negeri 5 Wangi-Wangi. The sampling technique used purposive sampling in which 12 students were taken from grade VIII students of SMP Wangi-Wangi. Data analysis technique was performed using Wilcoxon test analysis of data gain using SPSS version 16.0 for Windows by looking at the significance value or Asymp. Sig (2-tailed) $<0.05$, then the hypothesis is accepted, but if the significance value or Asymp. $\mathrm{Sig}$ (2-tailed)> 0.05 then the hypothesis is rejected. The results showed an overview of students before being given Gestalt Group Counseling on the pre-test results in the high category 8 students with the percentage $(100 \%)$ categorized as moderate $(0 \%)$ and low category $(0 \%)$. And on the post-test results in the high category $(0 \%)$, the medium category was 3 students with a percentage of $37 \%$ and the low category was 5 students with a percentage of $63 \%$. In Wilcoxon test is used to compare the differences in the pre-test and post-test values in the experimental group, so that the significance value or Asymp is obtained. Sig (2-tailed) $0.001<0.05$, then the hypothesis is accepted. Which means it can be denied that the Gestalt Group Counseling is effective in reducing the debate of students facing Semester Exams for Grade VIII students of SMP 5 Wangi-Wangi. Based on the results of this study, the advice that can be delivered is about more varied counselors and an increase in the frequency of providing information services to assist students in reducing student anxiety in Semester exams appropriately.
\end{abstract}

Keyword: Gestalt Group Counseling; Student's Anxiety

\section{PENDAHULUAN}

Proses pendidikan dan pengajaran akan selalu mengacu pada program yang terencana. Salah satu program tersebut dengan mengadakan tes atau ujian untuk mengetahui perubahan tingkah laku, baik potensial maupun actual dan kecakapan baru yang dicapai oleh siswa setelah 
mengikuti proses belajar mengajar. .Tetapi sering kali siswa menganggap ujian sebagai momok sehingga timbul kecemasan ketika menghadapi ujian tersebut. Kecemasan ini muncul karenatekanan untuk berprestasi dari orang tua, guru juga tuntutan diri sendiri. Hal ini menyebabkan rasa malu pada diri siswa jika tidak berhasil memenuhinya.

Kecemasan adalah sesuatu yang menimpa hamper setiap orang pada waktu tertentu dalam kehidupannya. Kecemasan merupakan reaksi normal terhadap situasi yang sangat menekan kehidupan seseorang. Kecemasan bisa muncul sendiri atau bergabung dengan gejala-gejala lain dari berbagai gangguan emosi (Savitri Ramaiah, 2003:10).

Kecemasan adalah suatu perasaan yang sifatnya umum, dimana seseorang merasa ketakutan atau kehilangan kepercayaan diri yang tidak jelas asal maupun wujudnya (Sutardjo Wiramihardja, 2005:66).

Kecemasan menghadapi ujian menjadi penghambat belajar yang mengganggu kinerja fungsi-fungsi psikologis seseorang seperti konsentrasi,takut akan kegagalan, pembentukan konsep dan pemecahan masalah (Puspitasri, 2015). Pada tingkat kecemasan yang kronis dan akut,

seseorang akan mengalami gangguan fisik (somtik), seperti gangguan pencernaan, sering buang air, gangguan jantung, sesak di dada, gemetar bahkan pingsan. Jika siswa terus menerus mengalami perasaan cemas pada saat menghadapi ujian maka kinerja fungsifungsi kognitifnya melemah, sehingga akan terjadi penurunan prestasi belajar. Sejalan dengan pendapat Santrock mengatakan jika kecemasan yang di alami tidak dapat diatasi oleh para siswa maka dapat berakibat pada menurunnya kemampuan siswa dalam mengerjakan soal pada waktu ujian semester atau ujian nasional sehingga dapat menyebabkan siswa tersebut dinyatakan tidak lulus/tidak naik kelas karena tidak memenuhi standar minimal nilai kelulusan yang ditetapkan (Santrock, 2007).

Salah satu layanan dalam bmbingan dan konseling yang dapat digunakan untuk membantu mengurangi kecemasan siswa dalam menhadapi ujian adalah layanan konseling kelompok. Banyak pendekatan yang dapat digunakan dalam proses konseling. Untuk mengurangi kecemasan siswa menghadapi ujian semester pendekatan yang digunakan adalah dengan pendekatan Gestalt. Konseling kelompok Gestalt yang akan dilaksanakan adalah menggunakan teknik 
kursi kosong.

Konseling kelompok Gestalt bertujuan untuk membantu siswa mencapai kesadaran tentang apa yang mereka rasakan dan lakukan, memahami kenyataan serta bertanggungjawab terhadap pilihannya, juga mengapresiasi pengalaman siswa pada masa kini dan mengatasi kecemasan-kecemasan akibat harapan- harapan masa depan dan mengungkapkan pengalaman yang tak selesai dan dihubungkan dengan kehidupan sekarang.

Terapi Gestalt yang dikembangkan oleh Federick Perls adalah bentuk terapi eksistensial yang berpijak pada premis bahwa individu-individu harus menemukan jalan hidupnya sendiri dan menerima tanggung jawab pribadi jika mereka berharap mencapai kematangan. Karena bekerja terutama di atas prinsip kesadaran, terapi Gestalt berfokus pada apa dan bagaimana-nya tingkah laku dan pengalaman di sini dan sekarang dengan memadukan (mengintegrasikan) bagianbagian kepribadian yang terpecah dan tak diketahui. (Corey, 2010: 118).

Pendekatan Gestalt menaruh perhatian yang besar pada pemisahan fungsi kepribadian. Yang paling utama adalah pemisahan "top dog" dan "undardog". Menurut Levitsky dan Pearls (dalam Coray, 2010:133) berpendapat bahwa teknik kursi kosong adalah suatu cara untuk mengajak subyek agar mengeksternalisasikan introyeksinya. Triantono Safaria (dalam Melis Agustiani, 2017:13) mengatakan Kursi kosong merupakan salah satu teknik permainan peran dimana konseli memerankan dirinya sendiri dan peran orang lain atau beberapa aspek kepribadiannya sendiri yang dibayangkan duduk/berada di kursi kosong.

Berdasarkan studi awal yang dilakukan sebelumnya, pendekatan Gestalt telah banyak ditemui. Namun penelitian mengenai penerapan pendekatan Gestalt untuk mengurangi kecemasan siswa dalam menghadapi ujian semester masih belum banyak dilakukan dan ditemukan baik secara pustaka maupun online (internet). Oleh sebab itu, penelitian tentang mengurangi kecemasan siswa dalam menghadapi ujian semester melalui konseling kelompok Gestalt dilakukan. Adapun tujuan dari penelitian ini adalah untuk mengetahui dan mendeskripsikan efektivitas konseling kelompok Gestalt untuk mengurangi kecemasan siswa dalam menghadapi ujian semester kelas VIII SMP Negeri 5 Wangi-wangi Kabupaten Wakatobi. 


\section{METODE PENELITIAN}

Pendekatan penelitian yang digunakan dalam penelitian ini adalah pendekatan kuantitaif. Penelitian ini adalah peneliitian eksperimen. Desain penelitian yang digunakan adalah pre eksperimental dengan one group pretestposttes design yaitu suatu teknik untuk mengetahui efek sebelum diberikan dan sesudah perlakuan. Desain eksperimen ini, tidak menggunakan variabel kontrol dan sampel tidak pilih secara random. Penelitian ini dilaksanakan pada 6 Maret sampai 20 Mei 2019 di SMPN 5 Wangiwangi Wakatobi tahun akademik 2018/2019. Berikut tabel desain penelitian one group pretest-posttes design

Tabel. 1. One Group Pretest-Posttest Design

\begin{tabular}{ccc}
\hline Tes Awal & Perlakuan & Tes Akhir \\
\hline O1 & $\mathrm{X}$ & $\mathrm{O} 2$ \\
\hline
\end{tabular}

Berdasarkan tabel di atas dapat dijelaskan bahwa $\mathrm{O} 1$ merupakan tes awal (pre-test) dilakukan sebelum penerapan pendekatan konseling kelompok Gestalt, $\mathrm{X}$ adalah perlakuan (treatment) penerapan pendekatan konseling kelompok Gestalt, dan O2 merupakan tes akhir (Post-test) dilakukan setelah penerapan pendekatan konseling kelompok Gestalt.

Teknik pengumpulan data yang digunakan dalam penelitian ini adalah berupa alat Rencana Pelaksanaan Layanan Bimbingan dan Konseling (RPL), Rencana Pelaksanaan Layanan (RPL) Bimbingan dan Konseling adalah seperangkat alat pembelajaran yang disediakan oleh guru Bimbingan dan konseling (Konselor) sebelum memulai pemberian layanan yang berisi tentang layanan bimbingan, konseling, dan informasi. Konselor menyampaikan materi atau bahan ajar yang sesuai dengan isi RPL.

Adapun skala yang akan digunakan merupakan skala model Likert. Skala yang digunakan dalam teknik penelitian ini yaitu, skala kecemasan siswa dalam menghdapi ujian semeter. Skala disusun dengan empat alternatif jawaban yaitu SS (Sangat Sesuai), S (Sesuai), TS (Tidak Sesuai), dan STS (Sangat Tidak Sesuai). Tahapan pengumpulan data dilakukan dengan meminta subyek penelitian memberikan respon jawaban pada skala. Hasil dari jawaban subyek dilakukan penyekoran untuk aitem favourable (mendukung) jawaban SS diberi skor 4, S diberi skor 3, TS diberi skor 2, dan STS diberi skor 1, sedangkan aitem unfavourable (tidak mendukung) jawaban SS diberi skor 1, S diberi skor 2, TS diberi skor 3, dan STS diberi skor 4. Analisis data dalam perhitungan skala ini menggunakan bantuan SPSS 21. for 
windows.Berikut hasil deskripsi data skala kecemasan siswa dalam menghadapi ujian semester.

Tabel 2. Deskripsi Data Skala Kecemasan Siswa Dalam Menghadapi Ujian Semester

\begin{tabular}{|c|c|c|}
\hline \multirow{2}{*}{ Deskripsi } & \multicolumn{2}{|c|}{ Skor } \\
\hline & Pretest & Postest \\
\hline SkorMaksimal & 75 & 75 \\
\hline Skor Minimal & 42 & 54 \\
\hline Mean & 58.8 & 66.64 \\
\hline StandarDeviasi & 11.14 & 6.16 \\
\hline Emperikskormaksimal & 96 & 24 \\
\hline Emperikskor minimal & 96 & 24 \\
\hline
\end{tabular}

digunakan adalah statistik data kuantitatif dengan menggunakan perhitungan statistik statistik non parametrik. Adapun teknik perhitungan dengan menggunakan uji Wilcoxon Signed Rank test. Dalam upaya mengetahui efektivitas konseling kelompok Gestalt untuk mengurangi kecemasan siswa dalam menghdapi ujian semeter kelas VIII SMP Negeri 5 Wangiwangi, teknik analisis data dalam penelitian ini menggunakan bantuan SPSS 21. for windows.

\section{HASIL DAN PEMBAHASAN}

Berdasarkan validasi item-item dalam skala sikap kecemasan siswa menghadapi ujian semester, dari 60 pernyataan yang diuji coba, dinyatakan valid atau memenuhi kriteria. Berikut disajikan tabel hasil analisis reliabilitas.
Tabel 3. Hasil Reliabilitas Skala Kecemasan Siswa Dalam Menghadapi Ujian Semester

\begin{tabular}{|c|c|}
\hline Cronbach's Alpha & $\mathrm{N}$ of Items \\
\hline 931 & 60 \\
\hline
\end{tabular}
validitas dan reliabilitas menggunakan teknik alpha Cronbachsesuaitabel 2 di atas, diketahui bahwa indeks reliabilitas skala kecemasan siswa dalam menghadapi ujian semester sebesar 0,930 dengan jumlah item keseluruhan 60 item, berarti skor skala tersebut mampu mencerminkan 93\% dari variasi yang terjadi pada skor murni kelompok subyek yang bersangkutan, dengan kata lain bahwa 7\% dari perbedaan skor yang tampak akibat variasi error atau kesalahan pengukuran.

Kategorisasi pada variabel dengan menetapkan kriteria kategori yang didasari oleh suatu asumsi bahwa subyek dalam populasi terdistribusi menurut model normal, untuk mengetahui tinggi rendahnya skor yang diperoleh subyek dapat dilakukan pengkategorisasian dengan menerapkan suatu kriteria. Skor yang diperoleh subyek diklarifikasikan menggunakan 3 kategori yaitu rendah, cukup, dan tinggi. Kriteria kategorisasi didasarkan pada standar deviasi dan mean hipotetik (Azwar, 2012). Kategorisasi yang akan digunakan adalah katgorisasi 
jenjang berdasarkan distribusi normal. Norma kategorisasi skor dapat dilihat pada tabel berikut.

Tabel 4. Norma Kategorisasi

\begin{tabular}{cc}
\hline Interval kategorisasi & $\begin{array}{c}\text { Norma } \\
\text { kategorisasi }\end{array}$ \\
\hline$X<(\mu-1,0 \delta)$ & Rendah \\
$(\mu-1,0 \delta) \leq X<(\mu+1,0 \delta)$ & Sedang \\
$(\mu+1,0 \delta) \leq X$ & Tinggi
\end{tabular}

Keterangan:

X: Skor skala

$\delta$ : Standar deviasi

$\mu:$ Mean/rerata

Berdasarkan norma kategorisasi

diatas dengan tiga kategori yaitu tinggi, sedang, dan rendah. Penjelasan ketiga kategori perilaku kecemasan siswa menghadapi ujian semester disajikan dalam tabel 5 berikut.

Tabel 5. Kategorisasi Skor

\begin{tabular}{cc}
\hline Interval kategorisasi & Norma kategorisasi \\
\hline $\mathrm{X}<120$ & Rendah \\
$120 \leq \mathrm{X}<180$ & Sedang \\
$180 \leq \mathrm{X}$ & Tinggi
\end{tabular}

Kategorisasi tersebut didasarkan pada nilai mean hipotetik dan standar hipotetik masing-masing variabel yang dapat dilihat pada tabel berikut ini

Tabel 5.Kategorisasi Kecemasan Siswa Dalam Menghadapi Ujian Semester

\begin{tabular}{ccccc}
\hline & $\begin{array}{c}\text { Interv } \\
\text { al }\end{array}$ & $\begin{array}{c}\text { Freku } \\
\text { ensi }\end{array}$ & $\%$ & $\begin{array}{c}\text { Kategori } \\
\text { sasi }\end{array}$ \\
\hline Pretest & $\mathrm{X}<$ & 1 & 8 & Rendah \\
kecemasa & 120 & & & \\
\cline { 2 - 5 } n siswa & $\begin{array}{c}120 \leq \\
\mathrm{X}<\end{array}$ & 3 & 25 & Sedang \\
& 180 & & & \\
\cline { 2 - 5 } & $\begin{array}{c}180 \leq \\
\mathrm{X}\end{array}$ & 8 & 67 & Tinggi \\
& Total & $\mathbf{1 2}$ & $\mathbf{1 0}$ & \\
\hline
\end{tabular}

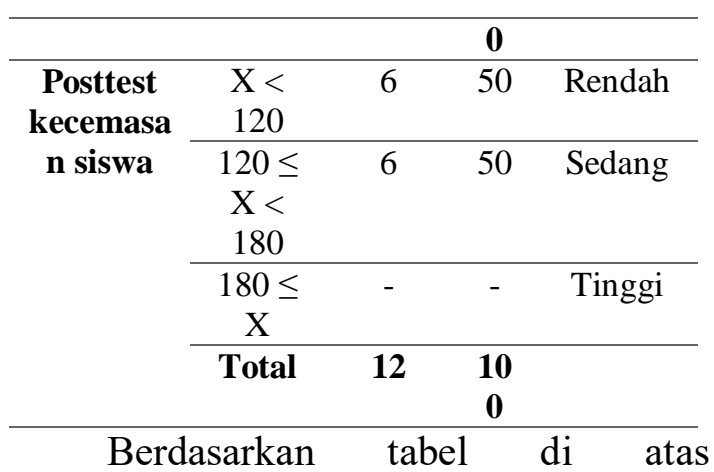

kategorisasi pretest menunjukkan dari 12 siswa, 1 siswa atau $8 \%$ subyek dalam kategori memiliki kecemasan dalam menghadapi ujian semester yang rendah, dan 3 siswa atau 25\% subyek dalam kategori sedang, dan 8 siswa atau $67 \%$ subyek memiliki kecemasan dalam menghadapi ujian semester yang tinggi. Sehingga dapat ditarik kesimpulan bahwa beberapa subyek penelitian memiliki kecemasan dalam menghadapi ujian semester yang cukup dan baik, selebihnya adalah siswa memiliki kecemasan dalam menghadapi ujian semester yang masih tinggi. Jumlah 8 sampel inilah yang peneliti gunakan dalam penelitian dengan menerapkan pendekatan Gestalt.

Hasil kategorisasi posttest, pada tabel 5 tersebut menunjukkan adanya peningkatan yang cukup baik. Berdasarkan hasil postest di atas, dijelaskan bahwa dari 12 sampel penelitian, kecemasan dalam menghadapi ujian semester meningkat pada kategori sedang sebanyak 6 siswa atau $50 \%$ dan pada kategori rendah sebesar 6 siswa atau 
$50 \%$ subyek telah memiliki kecemasan dalam menghadapi ujian semester yang baik (menurun). Sehingga dapat disimpulkan bahwa pemberian perlakuan dengan pendekatan Gestalt dapat menurunkan kecemasan dalam menghadapi ujian semester. Berikut diagram perbedaan hasil pretest dan posttest skala sikap kecemasan siswa dalam menghadapi ujian semester sebelum dan setelah diberi perlakuan.

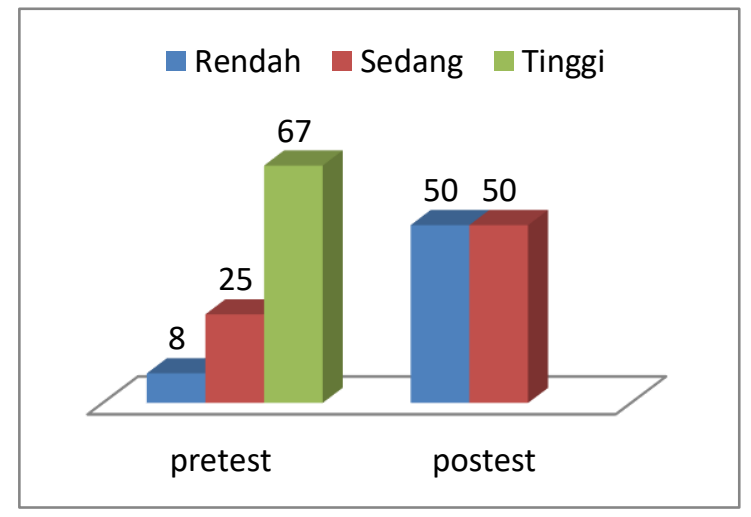

Grafik 1. Perbandingan Hasil Pretest Dan Postest Kecemasan Siswa Menghadapi Ujian Semester

Berdasarkan grafik di atas menunjukkan bahwa ada perbedaan yang signifikan antara hasil pretest dan posttest untuk menurunkan kecemasan siswa menghadapi ujian semester pada kelas VIII SMP Negeri 5 Wangi-wangi dengan menerapkan konseling kelompok melalui pendekatan Gestalt Hasil posttest tersebut menunjukkan bahwa konseling kelompok Gestalt dapat menurunkan kecemasan siswa menghadapi ujian semester.

Hal tersebut menunjukkan bahwa sebagian siswa kelas VIII SMP negeri 5 Wangi-Wangi memiliki tingkat kecemasan yang tinggi dalam menghadapi ujian semester atau secara presentasi dalam kategori rendah, oleh sebab itu dalam penelitian ini diberikan layanan konseling kelompok, dimana tujuan utama dari layanan konseling kelompok adalah berkembangnya kemampun sosialisasi siswa, khususnya kemampuan komunikasi peserta layanan. Dalam kaitan ini sering menjadi kenyataan bahwa kemampuan bersosialisasi/berkomunikasi seseorang terganggu oleh perasaan, pikiran, persepsi, wawasan, dan sikap yang tidak obyektif, sempit danter kungkung serta tidak efektif. Melalui layanan konseling kelompokhal-hal yang mengganggu atau menghimpit perasaan dapat diungkapkan, dilonggarkan, diringankan melalui berbagai cara. Pikiran yang suntuk, buntu, atau beku dicairkan dan di dinamiskan melalui berbagai masukkan dan tanggapan baru. Sedang fokus utama konseling Gestalt adalah terletak pada bagaimana keadaan konseli sekarang serta hambatan-hambatan apa yang muncul dalam kesadarannya. Oleh karena itu tugas konselor adalah mendorong konseli untuk dapat melihat kenyataan yang ada pada dirinya serta mau mencoba menghadapinya. Dalam hal ini perlu 
diarahkan agar konseli mau belajar menggunakan perasaanya secara penuh. Untuk itu konseli bisa diajak untuk memilih dua alternatif, konseli akan menolak kenyaataan yang ada pada dirinya atau membuka diri untuk melihat apa yang sebenarnya terjadi pada dirinya sekarang.

Berdasarkan hasil pretest tersebut menunjukkan kecemasan siswa dalam menghadapi ujian dipandang perlu untuk diturunkan melalui indicator kecemasan berdasarkan Jenild et al 1978 dalam (Esty R 2009:27) yang diterapkan dalam penelitian ini, dijabarkan sebagai berikut :

\section{1) Ketegangan}

Seseorang merasakan senang dan rileks. Hal tersebut tampak melalui perilaku siswa yaitu siswa terlihat tegang dalam mengerjakan soal yang diberikan..

2) Ketidaknyamanan

Seseorang merasa tertarik sehingga merasa nyaman untuk mengikuti pelajaran dan menyelesaikan soal yang diberikan hal tersebut tampak siswa merasa tidak nyaman dan tidak tertarik dengan soal yang diberikan dan juga tidak nyaman dalam menerima pelajaran.

3) Khawatir

Individu memperhatikan pelajaran dan soal yang diberikan sehingga merasa yakin atas apa yang dilakukan. Hal tersebut tampak siswa merasa was-was atas apa yang dikejakan.
4) Tidak senang dengan temannya

Individu merasa senang dan tertarik untuk bekerjasama dengan temannya dalam mengerjakan tugas yang diberikan. Hal tersebut tampak siswa tidak senang dengan teman kelompoknya.

5) Pesimis

Individu yakin dan percaya atas hasil yang dilakukan. Hal tersebut Nampak siswa tidak memiliki kepercayaan dan keyakinanatas soal yang telah dikerjakan.

6) Merasa tertekan

Seseorang melakukukan atau mengerjakan tugas dengan senang hati tanpa paksaan. Hal tersebut tampak siswa merasa tertekan dalam mengerjakan tugas atau soal yang diberikan.

7) Kehilangan harapan

Seseorang merasa memiliki harapan yang besar terkait masa depannya. Hal tersebut tampak siswa pesimis atas apa yang telah dilakukan.

Pengujian hipotesis penelitian ini. menggunakan perhitungan SPSS (statistical Product and Service Solutions) versi 16.0 for Windows. Penelitian ini Uji Wilcoxon. Untuk menguji hasil analisis skor sebelum dan sesudah pemberian perlakuan dengan layanan konseling kelompok gestalt untuk menurangi 
kecemasan siswa menghadapi ujian. Untuk lebih jelasnya dapat di lihat pada tabel di bawah ini:

Tabel 7. Hasil Analisis Tes Statistik Wilcoxon

\begin{tabular}{lcc}
\hline Kelompok & Z & $\begin{array}{c}\text { Asymp. Sig. (2- } \\
\text { tailed) }\end{array}$ \\
\hline $\begin{array}{l}\text { Pretest- } \\
\text { Postest }\end{array}$ & $-2.366^{\mathrm{a}}$ & 0.001 \\
\end{tabular}

Berdasarkan tabel 6 hasil analisis Wilcoxon setelah diberikan perlakuan dengan konseling kelompok Gestalt menunjukkan kecemasan siswa dalam menghadapi ujian semester siswa berada pada kategori rendah atau baik. Hal tersebut menunjukkan bahwa ada perbedaan yang signifikan antara kelompok pretest dengan kelompok posttest dengan nilai masing-masing nilai Asymp. sig. (2-tailed) probabilitas 0.001 pada taraf signifikansi nilai 0.05 $(\mathrm{p}<0.05)$, yang berarti dapat disimpulkan bahwa teknik token economy melalui layanan konseling kelompok Gestalt untuk mengurangi kecemasan siswa dalam menghadapi ujian semester kelas VIII SMP Negeri 5 Wangi-wangi yang dilakukan berhasil secara signifikan atau efektif untuk dilakukan.

Berdasarkan hasil penilaian segera awal diketahui bahwa layanan konseling kelompok Gestalt akan diberikan pada siswa ketika mereka menghadapi ketegangan dan kesulitan pada saat menghadapi ujian atau pada saat mereka mengalami kesulitan dalam memahami soal-soal dalam ujian. Hal ini akan menimbulkan kebosanan dan kurangnya minat siswa dalam belajar. Oleh karena itu setiap memberikan konseling kelompok Gestalt selayaknya seorang guru BK mampu menurunkan kondisi kecemasan siswa menghadapi ujian baik secara sengaja ataupun tidak sengaja. Maka kebiasaan pesimis, gelisah dapat pula dibentuk melalui saran-saran yang dapat dilakukan untuk menurunkan kecemasan siswa menghadapi ujian yang baik.

Layanan konseling kelompok Gestalt diberikan sebanyak delapan kali pertemuan. Setiap pertemuan, peneliti memberikan materi yang sesuai dengan indikator kecemasan siswa dalam menghadapi ujian semester dan kegiatan diskusi kelompok dalam hal ini siswa diharapkan dapat menurunkan kecemasan siswa dalam menghadapi ujian semester melalui layanan konseling kelompok. Pada proses pengamatan dalam pemberian layanan, setiap pertemuan siswa mengalami perubahan sikap dan perilaku yang baik seperti siswa mulai menampakkan menurunnya perasaan tegang, gelisah, khawatir, ketidak nyaman dan pesimis.

Berdasarkan hasil pengamatan 
setelah postest, siswa mulai menunjukkan penurunan kecemasannya berdasarkan aspek-aspeknya atau indikatornya yaitu sebagai berikut:

\section{1) Ketegangan}

Setelah diberikan perlakuan melalui konseling kelompok gestalt, siswa mulai memiliki perasaan senang untuk mengerjakan soal yang diberikan. Hal tersebut tampak melalui perilaku siswa yaitu siswa terlihat lebih rileks dalam mengikuti konseling dan proses belajar di kelas dan tak terlihat tegang dalam mengikuti konseling dan dalam mengerjakan soal yang diberikan..

2) Ketidaknyamanan

Setelah pemberian perlakuan dengan konseling kelompok Gestalt, siswa mulai menampakkan ketertarikan dirinya untuk mengikuti pelajaran dan menyelesaikan soal yang diberikan disebabkan karena ada hal baru yang dilakukan oleh guru atau pun peneliti ketika memberikan konseling dan rasa aman.

\section{3) Khawatir}

Setelah penerapan konseling kelompok gestalt, siswa mulai memiliki perhatian dalam mengikuti konseling dan proses belajar dalam hal ini siswa mulai memberikan perhatiannya dan guru ataupun peneliti memberikan hal-hal baru yang dapat menarik perhatian siswa.
4) Tidak senang dengan temannya

Setelah pemberian perlakuan dengan konseling kelompok Gestalt, siswa mulai menampakkan rasa senang dalam mengikuti pelajaran dan kegiatan kelompok bersama temannya disebabkan karena ada hal baru yang dilakukan oleh guru atau pun peneliti ketika memberikan konseling dan menyampaikan tema.

\section{5) Pesimis}

Setelah pemberian perlakuan dengan konseling kelompok Gestalt, siswa mulai menampakkan percaya dirinya dan yakin untuk mengerjakan soal-soal yang diberikan oleh gurunya ini disebabkan atas perlakuan guru dan peneliti dalam memotivasi siswa.

6) Merasa tertekan

Setelah diberikan perlakuan melalui konseling kelompok gestalt, siswa mulai memiliki perasaan senang, tanpa keterpaksaan untuk mengerjakan soalsoal. Hal tersebut tampak melalui perilaku siswa yaitu siswa terlihat lebih rileks dalam mengikuti konseling dan terbuka dalam menyampaikan perasaan tertekannya.

7) Kehilangan harapan

Setelah penerapan konseling kelompk gestalt, yang tampak adalah siswa terlibat dan aktif serta yakin akan kemampuannya dalam mengerjakan tugas 
serta soal yang diberikan. Siswa mulai mengikuti konseling dan pelajaran dengan baik, dan yakin atas apa yang dikerjakan.

Adapun ditinjau dari seluruh indicator kecemasan siswa dalam menghadapi ujian semester, sebelum dan setelah diberikan perlakuan juga mengalami perubahan yaitu berupa penurunan kecemasan siswa dalam menghadapi ujian semester yang cukup baik atau dalam persentasi dikategorikan sedang. Dalam penerapan konseling kelompok gestalt tanggung jawab keberhasilan konseling berada di tangan konseli (dalam penelitian ini adalah siswa yang menjadi sampel penelitian).

Konseling kelompok gestalt lebih memfokuskan pada perasaan klien, kesadaran pada saat yang sedang berjalan, serta hambatan terhadap kesadaran.; Menantang klien sehingga mereka mau memanfaatkan indera mereka sepenuhnya dan berhubungan dengan pesan-pesan tubuh mereka; Menaruh perhatian pada bahasa tubuh klien, sebagai petunujuk non verbal; Secara halus berkonfrontasi dengan konseli guna untuk menolong mereka menjadi sadar akan akibat dari bahasa mereka.

Hasil yang diperoleh setelah kecemasan siswa menurun siswa lebih mampu menyusun sepenuhnya dari bagian-bagian yang saling berkaitan. Konseli mampu memperhatikan dan mengamati bagian tubuh, emosi, pikiran, sensasi dn persepsi bisa dimengerti jika terpisah dari keseluruhan konteks pribadinya, Individu-individu juga bagian dari lingkungannya sendiri dan tidak bisa dimengerti jika terpisah darinya, Individu-individu memilih cara mereka merespons stimuli eksternal dan internal; mereka adalah aktor bukan reactor, Individu-individu memiliki potensi untuk menyadari sepenuhnya semua sensasi, pikiran, emosi dan persepsi, Individuindividu sanggup melakukan pilihan tertentu karena sadar betul akan dirinya, lingkungannya dan kebutuhannya., Individu-individu memiliki kapasitas untuk mengatur hidup mereka sendiri secara efektif. Individu-individu tidak bisa mengalami masa lalu dan masa depan. Mereka dapat mengalami hanya diri mereka di masa kini (di sini dan sekarang)., Individu pada dasarnya bukan baik atau buruk.

Peningkatan hasil intervensi proses konseling kelompok Gestalt merupakan salah satu usaha atau tindakan efektif guru BK dalam melaksanakan layanan konseling kelompok di sekolah, hal ini sangat efektif manakala konseling kelompok Gestalt dilaksanakan 
berdasarkan Rencana dan mengikuti jadwal waktu untuk belajar yaitu dengan meningkatkan kesadaran dirinya; mengadakan penilaian terhadap kesulitan bahan untuk dipelajari lebih lanjut menyusun dan membuat pertanyaanpertanyaan yang tepat, dan berusahakan atau mencoba untuk menemukan jawabannya; memusatkan perhatian dengan sungguh-sungguh pada waktu belajar; mempelajari dengan teliti tabeltabel, grafik-grafik dan bahan ilustrasi lainnya; dan selalu membiasakan membuat rangkuman dan kesimpulan.

Menurut Perls (Corey, 2010: 128) pada pelaksanaan konseling dengan pendekatan Gestalt, konselor membiarkan konseli menemukan sendiri potensipotensinya yang hilang. Selain itu konselor menyajikan situasi yang menunjang pertumbuhan dengan jalan mengonfrontasikan konseli kepada titik tempat konseli menghadapi suatu putusan apakah akan atau tidak akan mengembangkan potensi-potensinya.

Berdasarkan uraian tersebut di atas menunjukkan bahwa ada perubahan yang signifikan yaitu penurunan kecemasan siswa dalam menghadapi ujian semester pada semua indikator yang diterapkan. Meskipun demikian, hendaknya perlu dikembangkan lagi terkait dengan kecemasan siswa dalam menghadapi ujian menurut beberapa teori lain. Maka dapat disimpulkan bahwa konseling kelompok gestalt melalui layanan konseling kelompok efektif untuk menurunkan kecemasan siswa dalam menghadapi ujian semester kelas VIII SMP Negeri 5 Wangi-wangi.

\section{PENUTUP}

Berdasarkan hasil penelitian secara umum dapat disimpulkan bahwa konseling kelompok gestalt dapat mengurangi kecemasan siswa dalam menghadapi ujian semester, konseling kelompok gestalt efektif untuk dilakukan, karena siswa telah mampu mengatasi kecemasannya setelah diberikan perlakuan teknik yang diterapkan. Melalui konseling kelompok gestalt dengan 8 kali pertemuan telah mampu menurunkan kecemasan siswa dalam menghadapi ujian semester dengan kategori rendah 50\%, kategori sedang $50 \%$ yang sebelum diberikan perlakuan tingkat kecemasan siswa dengan kategori rendah $8 \%$, kategori sedang $25 \%$ dan kategori tinggi $67 \%$.

Rekomenasi bagi guru, dapat digunakan sebagai bahan pertimbangan guru bimbingan dan konseling atau konselor sekolah dalam melaksanakan Layanan konseling kelompok Gestalt untuk mengurangi kecemasan siswa menghadapi ujian semester SMP Negeri 5 
Wangi-wangi Kabupaten Wakatobi.

Bagi peneliti selanjutnya sebagai bagian referensi untuk mengembangkan tentang Layanan konseling kelompok Gestalt dengan menggunakan veriabel lain kesulitan siswa dalam mengikuti proses belajar di sekolah.

\section{DAFTAR PUSTAKA}

Anastasi,A.,\& Urbinal, S. 1997. Psychologycal Testing (7Tn ed) Toronto : PrenticeHall International Inc.

Atkinson, Rita Let al, 2008. Pengantar Psikologi. (11 th ed). Diterjemahkan oleh Dr Wijaya Kusuma. Batam : Interaksara.

Azwar, Syarifuddin. 2012. Penyusunan Skala Psikologi. Yogyakarta: Pustaka Pelajar

Boeree. G. 2008. Personality Theories. Melacak Kepribadian Anda bersama Psikolog Dunia. Diterjemahkan oleh Inyiak Ridwan Muzir. Yogyakarta ; PrismaSophie.

Corey, G. 2010. Teori dan Teknik Konseling dan Psikoterapi. Terjemahan oleh E. Koeswara. 2009. Bandung : PT. Refika Aditama.

Dewi. \& Rustam. 2008. Perbedaan Kecemasan menghadapi SPMB anrtara Siswa Kelas Akselerasi dan Kelas Regular. Jurnal Pusat Keberbakatan Fakultas Psikolog UI Edisi Pebruari 2008.

Esty R. 2009. Efektivitas Konseling Rasional Emotif Dengan Teknik Relaksasi untuk Membantu Siswa Mengatasi Kecemasan Menghadapi Ujian atau Tes Siswa SMP N 5 Nganjuk. UNNES FIP ; Semarang.
Gibson, R. L \& Mitchell, M. H. (2011). Bimbingan dan Konseling di Perguruan Tinggi. Yogyakarta: Pustaka Belajar.

Gudnanto. 2012. Pendekatan Konseling. Program Studi Bimbingan dan Konseling UMK. FKIP.

K.H， Lidyartanti. $2016 \quad$ Efektifitas Layanan Konseling Kelompok Dengan Pendekatan Gestalt Terhadap Peningkatan Penyesuaian Diri Siswa Kelas VII SMP Negeri 1 Kalimanah, Purbalingga. Skripsi dipublishkan. Universitas negeri Yogyakarta

Latipun. 2008. Psikologi Konseling. Malang ; UPT Penerbitan Universitas Muhamadiyah Malang.

Natawdjaja R. 2009. Konseling Kelompok : Konsep Dasar \& Pendekatan. Rizqi Press; Bandung.

Prayitno dan Erman Amti. 2014. DasarDasar Bimbingan Konseling. Jakarta: Rineka Cipta

Puspitasari YP, Abidin Z, Sawitri DR.Hubungan antara Dukungan Sosial Teman Sebaya dengan Kecemasan Menjelang Ujian Nasional (UN) pada Siswa Kelas XII Reguler SMA Negeri 1 Surakarta. Semarang: Undip. 2010:1-15

R.S, Wijaya. 2016. Penerapan Konseling Menggunakan Model Pendekatan Psikologi. Depublish. CV. Budi Utama; Yogyakarta.

Santrock JW. Psikologi Pendidikan. Edisi Kedua. Cetakan 1. Alih bahasa Tri Wibowo B. S. Jakarta: Kencana. 2007:41-44

Suhendri. 2012. Model Konseling Kelompok Rational-Emotif Untuk Membantu Siswa Mengatasi 
Kecemasan Menghadapi Ujian (studi pada SMK Negeri 7 Semarang Tahun Ajaran 2011/2012). Jurnal Program Pascasarjana UNNES, dipublikasikan.

Tri Marsiyanti \& F. Harahap. 2000. Psikologi Keluarga. Yogyakarta: FIP. UNY.

Willis, S. 2004. Konseling Individual Teori dan Praktek. Bandung : Alfabeta.

Yusuf, S dan Juntika N. 2014. Landasan Bimbingan dan Konseling. (2 th ed) Jakarta : Program Pascasarjana Universitas Pendidikan Indonesia (UPI) ; PT Rosdakarya 